\title{
Bridging the Gap between Theory and Practice: Reviewing the Functions and Powers of Local Government in South Africa
}

Issue 2: January 2009

http://epress.lib.uts.edu.au/ojs/index.php/cjlg

\section{Annette Christmas and Jaap de Visser $^{1}$ \\ Community Law Centre, University of the Western Cape, South Africa}
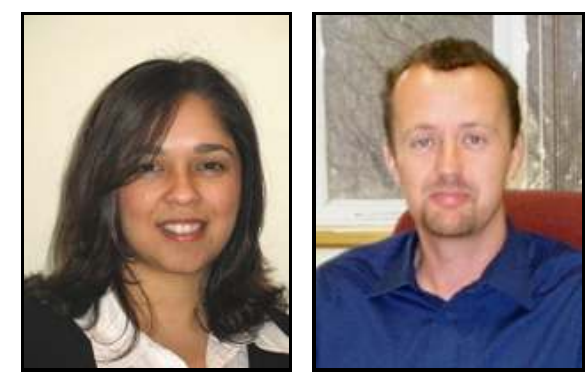

\section{Introduction}

The chairperson of the parliamentary Portfolio Committee on local government recently described local government in South Africa as "a chicken whose legs have been tied for too long". In other words, even when the fetters that bind the chicken's legs are loosed, it remains at a loss for what to do with its newfound freedom (Tsenoli 2007). This descriptive analogy ostensibly refers to the failure of local government to harness its newfound power in post-apartheid South Africa and to claim its rightful position as the driver of development at the local level, and instigator of bottom-up growth and progress, which is meant to shape and transform society in the new South Africa.

Of all the spheres of government, local government arguably has the most immediate developmental mandate to realise the ideal physical environment for the communities it serves (Constitution of the Republic of South Africa 1996, ss.152,

\footnotetext{
${ }^{1}$ This practice note is based largely on a research paper authored by De Visser and Christmas for the Community Law Centre: Developmental Local Government: Determining Appropriate

Functions and Powers. The full paper is available at $\langle$ http://www.communitylawcentre.org.za $>$.
} 
153). ${ }^{2}$ The 1998 White Paper on Local Government, ${ }^{3}$ echoing the developmental mandate entrenched in the Constitution, instructs municipalities to:

- Exercise their powers in a manner that maximises economic growth and social development

- Coordinate development activities of state and non-state agents in the municipal area

- Deepen democratic development through community participation

- Build social capital for increased sustainability.

This exacting developmental mandate is in keeping with the established principle of subsidiarity, which advocates that "public responsibilities should be exercised by those elected authorities who are closest to the people" (Governing Council of the United Nations Human Settlements Programme 2007). In other words, the impact of the collective efforts of national, provincial and local government in fulfilling their constitutional obligations to citizens must be tangibly seen and felt at the local level. The Constitution, together with the White Paper on Local Government, therefore entrenches the role of local government as the driver and guardian of such development.

The upcoming 2009 elections provide South Africans with the opportunity to reflect on how far we have come in the first 13 years of democracy, and on the extent to which constitutional ideals have been translated into reality. As part and parcel of this broader process, the then Minister for Provincial and Local Government, Sydney Mufamadi, launched a national review of provincial and local government on 31 July $2007 .{ }^{4}$ This process invites everyone, from civil servants to the private sector, tertiary education institutions and most importantly, ordinary South African citizens, to review the successes and failures of government in postapartheid South Africa. For local government in particular, the review process provides an opportunity to reflect on the experience of the new local government dispensation just eight years after it was first established. Importantly, this evaluation probes the extent to which the functions and powers delineated for local government have enabled it to meet its developmental mandate. It is the purpose of this practice note to evaluate the current allocation of functions and powers in the Constitution, and furthermore to propose a set of criteria to guide decisions on where powers and functions are best situated.

\footnotetext{
${ }^{2}$ The Constitution of the Republic of South Africa (hereafter the Constitution) obliges a municipality to "structure and manage its administration and budgeting and planning processes to give priority to the basic needs of the community and to promote the social and economic development of the community".

${ }^{3}$ The White Paper on Local Government, 1998 is a policy document which consolidates and elucidates the developmental mandate of local government entrenched in the Constitution. Local government legislation enacted in the wake of the White Paper is based on the policy directives contained therein.

${ }^{4}$ Following the resignation of former President Thabo Mbeki, there was a reshuffling of the Cabinet. Mr. Sicelo Shiceka MP, replaced Mr. Sydney Mufamadi as the Minister for Provincial and Local Government.
} 


\section{Balancing the Scales: Achievements vs. Challenges}

The transformation of South African local government from racialised, fragmented administrative centres under the apartheid government, to a constitutionally recognised, autonomous sphere of government, is described by many as phenomenal. In the face of seemingly insurmountable service delivery and infrastructure backlogs, the progress made by local government in extending basic services such as water, electricity and sanitation to the millions of citizens who were previously excluded from accessing these services, is significant. ${ }^{5}$ However, the varying levels of success achieved by municipalities in fulfilling these duties reflects the diversity which characterises local government.

Local government in South Africa is comprised of 283 municipalities, which range in population, size and resources from severely under-resourced rural municipalities to first class metropolitan giants ('metros'). The six metros currently house one third of South Africa's 48.7 million population. They are also considered to be the economic powerhouses of South Africa, collectively contributing 59\% of South Africa's GDP (South African Cities Network 2005). Despite these hubs of intense development and economic growth, South Africa on the whole remains one of the most unequal societies in the world in respect of wealth disparity. With the rapid rate of urbanisation most visible in the metros and cities, unprecedented levels of development often co-exist alongside conditions of abject poverty. While levels of service delivery have been attained at the local level, the developmental mandate of local government as set out in the White Paper extends much further than basic service delivery. This mandate, however, can only be achieved if municipalities are equipped with the appropriate functions and powers to fulfil these roles.

\section{Stumbling Blocks to Development}

There are a number of inherent challenges that present stumbling blocks to local government achieving its full developmental potential.

\section{Autonomy}

The decentralised governance model adopted in the Constitution designates specific powers and functions to each sphere of government, which are enjoined to work together "to secure the well-being of the people of the Republic" (Constitution of the Republic of South Africa 1996, s.41(1)(b)).

As appropriate as such a vehicle for co-operative governance may seem within a democratic context, having three spheres of government operating each with a degree of autonomy makes for complex relationships, which also impact on the effectiveness and efficiency of government. As a relatively new sphere, local

\footnotetext{
${ }^{5}$ For elaboration on the roll-out of services by local government, see budget speech by the then Minister for Provincial and Local Government, Sydney Mufamadi, on 2 June 2008. Accessed on 10 October 2008 at 〈http://www.polity.org.za $>$.
} 
government is faced with the challenge of establishing its autonomy. National and provincial government have therefore had to re-conceptualise their political attitudes towards local government in line with the new constitutionally entrenched ideal of developmental local government. In practice, however, different approaches are evident across sector departments. These approaches range from being respectful of local government autonomy to clearly patronising. ${ }^{6}$

\section{Service Delivery and Infrastructural Backlogs}

As stated above, municipalities inherited huge service delivery and infrastructural backlogs from the apartheid system of governance. They also faced a lack of capacity and skills to deliver at the local level. In the restructuring of local municipalities in 2000, much of the institutional memory of local government was lost. A major concern often voiced is that appointment of municipal staff is at times made on the basis of political patronage and not necessarily skills and expertise. While government has attempted to address capacity deficits through Project Consolidate (a program that deploys skilled workers to particularly weak municipalities to assist in capacity building - see $<$ http://www.projectconsolidate.gov.za $)$, there are concerns that this initiative is not enough. Deficits in scarce, specialised skills such as engineering, are fast becoming critical.

\section{Pervasive Poverty}

The World Bank report for 2006 ranks South Africa as one of the most unequal societies in the world (World Bank 2008). The saturated labour market and growing unemployment rate, coupled with the effects of the worldwide recession, have made it increasingly hard for the poor in South Africa to attain basic minimum living standards (Triegaardt 2008). Local government, while developmental in nature, cannot be held solely responsible for making in-roads into the pervasive poverty which permeates South Africa.

\section{Poorly Defined Functions and Powers}

One of the most pressing challenges facing developmental local government, and which comprises the subject matter of this paper, is poorly defined functions and powers. Poorly defined powers and functions have been a source of great concern and confusion for municipalities since the creation of the new local government dispensation. This lack of clarity has often resulted in duplication of duties, confusion, inefficiencies and arguably even deterioration in the delivery of services to communities. In worst case scenarios it has led to intense animosity between provincial governments and municipalities, who reach an impasse in respect of

\footnotetext{
${ }^{6}$ De Visser (2008:6) describes two very different attitudes expressed by the respective national departments of Trade and Industry (DTI) and Minerals and Energy (DME) pertaining to municipal powers to prescribe the installation of solar water heaters in new buildings erected within the municipal jurisdiction. The DTI makes such powers subject to national approval, while the DME correctly assumes that municipalities have the inherent power to make their own by-laws on the matter.
} 
which sphere should perform a particular function. This has even led to situations where neither sphere wishes to take responsibility for a contested function.

The impact of poorly defined powers and functions can have far-reaching consequences. There is, therefore, growing concern about the manner in which the Constitution currently distributes functions and powers. ${ }^{7}$ In addition, the mechanisms employed by national and provincial governments to allocate additional functions to local government do not comply with the legislative framework enacted to regulate such transfers. At times, these transfers of functions and powers only serve to perpetuate the gap between the functional and fiscal resources of municipalities, and the vision of developmental local government which South Africa is seeking to attain.

\section{Sources of Local Government Functions and Powers}

\section{'Original' Powers of Local Government}

Schedules $4 \mathrm{~B}$ and $5 \mathrm{~B}$ of the Constitution list the functional areas that are the responsibility of local government. The Constitution provides municipalities with the necessary legislative and executive powers to administer and fulfil these functions (Constitution of the Republic of South Africa 1996:ss.156(a), 156(2)). These are the most significant of local government's powers, and are referred to as 'original' powers because they are sourced directly from the Constitution. As such, these powers are safeguarded and may not be removed or amended by ordinary statutes or provincial Acts. Any change would therefore have to be effected by amending the Constitution itself.

The 'original' powers, however, do not correspond to the prescription of developmental local government. A cursory evaluation of the listed functions and powers reveals a mixed bag of competencies which do not necessarily relate to each other or to a strategic, over-arching developmental mandate. ${ }^{8}$ Municipalities, for example, lack the policy-making and financial authority to achieve developmental objectives in critical 'high impact areas' such as housing and local economic development. This creates an untenable situation where municipalities must rely on external actors to initiate and drive development initiatives that pertain to these functions.

\footnotetext{
${ }^{7}$ Finance Minister Trevor Manuel, when addressing the National Council of Province's Intergovernmental Relations (IGR) Summit in 2007 made an appeal for an 'objective look' at whether the current configuration of powers and functions, including the constitutional aspects, is appropriate. See: Trevor Manuel, MP, 'Co-operative governance and intergovernmental fiscal relations' Address at the National Council of Provinces (NCOP) Summit (Cape Town: 3 May 2007).

${ }^{8}$ For example Schedules 4B and 5B include functions which range from building regulations and municipal public transport to licensing of dogs, cleansing, and traffic and parking, to mention just a few.
} 


\section{Have the Schedules Kept Pace with Reality?}

Another key question relates to whether the Schedules of the Constitution have remained relevant in the aftermath of the comprehensive demarcation of new municipalities for post-apartheid South Africa that took effect in 2000. It seems evident that the powers listed in the 1996 Constitution have not 'caught up' with that demarcation process. The approach taken in the Schedules to management of the built environment at the local level is a case in point. ${ }^{9}$

Municipalities in South Africa perform a myriad of functions that centre around the management of space. Land use planning, delivery of potable water, electricity and sanitation are key examples of this, Furthermore, municipalities are instrumental in the extension of water, sanitation, electricity and road infrastructure. Even a municipality's prime income source, property rates, has a significant spatial component to it.

The demarcation of municipal boundaries in 2000 was primarily concerned with reconfiguring municipal space as a result of the exigencies inherited from the apartheid system of local government. Rationalising the numerous municipalities that served the different racial groups constituted the crux of this exercise. The demarcation process therefore saw the creation of contiguous municipal space in the form of large municipal areas. A logical consequence of this demarcation should have been the allocation of concomitant powers to drive development within this space.

The allocation of functions as it appears in the Schedules however, does not reflect this change. Management of the built environment is disaggregated. In the Schedules, the functions of planning, housing and transport are treated as distinct from each other. Housing is not a local government function but is a concurrent national and provincial function that is implemented with municipal assistance. This disaggregation applies not only to the way the function is defined, but the manner in which it is allocated across spheres. The Schedules for example, separate provincial transport and planning from municipal transport and planning. Confusion thus exists with regard to a municipality's power with regard to land use management and public transport.

Management of the built environment should logically be comprised of an integrated set of functions which have an immediate impact on municipal space, including:

- Planning

- Urban areas

\footnotetext{
${ }^{9}$ The points discussed under this heading emanate from a Roundtable meeting hosted by the Community Law Centre on 5-7 March 2008 in Stellenbosch, Cape Town. The Roundtable was based on the initial outcomes of the review process of provincial and local government which is currently underway. These discussion points are extracted from the report on the Roundtable which was authored by Annette Christmas and is accessible at: $\langle$ http://www.communitylawcentre.org.za $>$.
} 
- Management of space and movement across space

- Transport

- Housing

- Infrastructure that supports transport and housing.

In order to foster development in an integrated and coherent fashion, cities should be empowered to drive these key processes without depending on external agencies and institutions. While it is true that national and provincial governments can allocate additional powers to local government by means of assignment, delegation or agency, these sources of power do not enjoy the same level of protection as the 'original' powers of local government. Because developmental local government is a concept which is based in the Constitution itself, Schedules 4B and 5B should not contradict this intention and limit a municipality's ability to fulfil this mandate.

\section{Additional Powers and Functions}

The Constitution together with the Local Government: Municipal Systems Act (32 of 2000) outlines the appropriate procedures for transferring functions to municipalities. These procedures seek to ensure that the assignment of powers outside the constitutional competencies of municipalities is well placed, that legislative and executive capacity is transferred, and that municipalities are safeguarded against unfunded mandates. However, while virtually all national and provincial sectors acknowledge the importance of municipalities and engage them in service delivery, they almost never do so by using the appropriate means of transferring functions. In practice, delegation and agency are the most commonly used means of transferring powers to local government, which reduces the role of local government to that of service deliverers or implementing agents of national and/or provincial governments. Other mechanisms for transferring functions include sector-specific instruments similar to delegation. The housing accreditation process is an apt example of how the transfer of a function and the terms of implementation thereof is strictly regulated by another sphere of government. Housing is currently a Schedule A function, which means that it is a concurrent function shared by national and provincial government. As such, municipalities have to apply to provincial government to become entities accredited to administer national housing programmes or to become housing developers. If accredited, there is no permanency in respect of the transfer of powers and municipalities are bound by the terms of the agreement concluded with the provincial government, once again reducing them to implementers rather than the drivers of development.

The requirements for accreditation are outlined in the National Housing Code (National Housing Code 1997, Part 2, Chapter 2). Accreditation is not a suitable mechanism for the devolution of the housing function to local government. Notwithstanding the fact that in practice very few, if any, municipalities have been accredited (South African Local Government Association 2007), the exclusionary nature of the process means that certain municipalities are enabled to perform the housing function in a manner that facilitates their developmental mandate, while others are completely excluded from the opportunity until they are able to meet the 
requirements of accreditation. There is, therefore, a disproportionate benefit for citizens who are the beneficiaries of housing initiatives within the jurisdiction of municipalities which have been accredited.

The difficulties encountered in the accreditation process represent the first hurdle that municipalities have to overcome even before leaving the starting blocks. One challenge relates to a lack of understanding of the application process (Department of Housing KwaZulu-Natal 2005), and the arguably high threshold requirements for accreditation. For example the 'proven track record' requirement stipulates that: "the Council's proven track record of initiatives and involvement in housing provision and/or community development in its area of jurisdiction will be a recommendation" (Ibid 2005). In respect of capacity, it is a pre-requisite that the municipality should have "financial, administrative, professional and technological capacity to fulfil its housing responsibilities and to administer the National Housing Programmes." It is difficult to conceive of many municipalities who currently have that level of infrastructure, as the appropriate kind of capacity is unlikely to emerge without the existence of authority.

The consequence of this mechanism for transferring a function is aptly demonstrated in the Western Cape. The Western Cape provincial government has consistently denied the City of Cape Town's application to be accredited to perform the housing function, prompting the metro to declare an intergovernmental dispute with the province. The mayor of the City of Cape Town, Helen Zille, cited "red tape delays with the municipality's own projects, especially when it comes to housing" as a key impediment to delivery (Zille 2007). Even the smallest metro, Nelson Mandela Bay, has categorically stated that it is "more than capable and is in fact already fulfilling this function." Despite this, housing remains a provincial function and local government, as the sphere of government which is most accessible to the people, often has to bear the brunt of community dissatisfaction in the face of delivery failures.

Another significant consequence of fragmented sector-based efforts to involve local government is that municipalities often end up bearing the hidden overhead costs associated with the function. This is because the protection against unfunded mandates offered by the Municipal Systems Act is not applicable to the instruments used.

\section{Enhancing the Governance Role of Local Government}

What, then, is the appropriate way to equip local government with the necessary authority to play a developmental role? First, there is a strong case for re-defining the existing competences listed in the Schedules. Apart from concerns about the content of the Schedules not providing appropriate authority to achieve developmental goals, there are also concerns about the manner in which competencies are defined in the Schedules. While broadly defined competencies are appropriate for national and provincial government, they are inappropriate for local government. They create overlap and confusion about the role of local 
government, which is often interpreted very narrowly. Local government competencies therefore need to be defined as precisely as possible.

Second, additional functions, where an authoritative policy role is envisaged for local government, must be transferred within the parameters of the legal framework established for assignment. In South Africa, in addition to the Constitution and Municipal Systems Act, 'Guidelines on Allocation of Additional Powers and Functions to Municipalities' were recently promulgated by the Department of Provincial and Local Government (2007). These guidelines attempt to infuse the assignment process with the necessary safeguards that would protect the interests of all parties to the assignment. Importantly, they assert that functions can be assigned either to individual municipalities or to local government as a sphere. A differentiated approach to assignment is therefore possible and appropriate, given the variety in capacity and economic and spatial realities present in municipalities.

\section{Indicators for Local Government Powers and Functions}

Having described the developmental mandate, the mismatch between mandate and powers, as well as the instruments available for intervention, the question is then: What powers and functions are best performed at local government level? A number of indicators emerge from national and international literature on decentralisation. These indicators are useful to determine at what level a particular function should be performed. They must be complemented by consideration of generic aspects such as the history and context of local government. In the South African case, this refers specifically to the special developmental role of local government, the need to redress the legacy of apartheid, and the political culture within which local government operates. In addition, any application of these indicators must take place against the backdrop of the principle of subsidiarity, which as stated above, advocates that governance should be located as close to citizens as possible.

Six indicators are proposed that could assist this assessment, using the housing function as an example.

- The degree to which economies of scale can be obtained at a higher level: if it is more efficient and cost-effective to perform a function at a supra-municipal level, this is an argument against allocating the function to local government.

- The degree of spill-over effects of a function: spill-over effects occur when residents from outside the municipal area make extensive use of, or benefit from the service. Examples of this include 'network' services, such as highways and telecommunications.

- The necessary capacity: the existence of capacity is key to the ability of local governments to perform their functions. However, it should not always be the decisive factor: it is important to avoid a 'Catch 22' dilemma 
whereby authority is withheld because of a lack of capacity, but capacity cannot emerge without the granting of authority. If authority and resources (both financial and human) are transferred jointly, capacity should develop as communities are entitled to, and expect, the delivery of services. As described above, an apt example of how the capacity argument is applied to slow down the transfer of authority to local government can be seen in the housing sector.

- The degree of intersectoral coordination: all government service delivery comes together in the municipal area, making local government the ideal coordinating agency. Multi-sectoral and multi-sphere integration should be achieved mainly through the Integrated Development Plan (IDP). ${ }^{10}$ Multi-sectoral coordination is vital in respect to housing which, by its very nature, is an integrating activity as it includes planning, land administration, housing recipient identification, delivery of a package of services, development facilitation and the provision of the house itself.

- The degree of grass roots community participation required: a strong indicator is the extent to which community participation is an essential part of the function. It can be argued that all government functions require public input, which could render the indicator meaningless. However, the type of engagement required may differ: public participation for the development of national social welfare policies is different from engaging the public on renaming municipal streets or establishing a housing development project. As the intensity of the required engagement increases, municipalities become best placed to perform the function. Housing is a function that requires highintensity, grassroots community participation. It is perhaps one of the most 'vulnerable' functions in this respect: if community participation is inadequate, successful implementation is easily hampered by disgruntled residents.

- The degree of policy control over the built environment: it is often argued that municipal responsibility centres on controlling the built environment, that is, the spatial and physical aspects of public service delivery and government regulation. This is supported by the White Paper vision of municipalities as facilitators of local economic growth.

Municipalities facilitate economic growth primarily through the provision of the infrastructure, necessary for economic activity. Key elements of infrastructure for economic growth include -

a. people infrastructure (proximity to personnel)

b. skills infrastructure (availability of skills)

c. financial infrastructure (currency, banking)

${ }^{10}$ An IDP is essentially a participatory process of planning through which the municipality assesses needs, prioritizes them and then formulates objectives and strategies to address them. The IDP should consolidate all municipal planning into a comprehensive strategy that is linked to the municipal budget. 

d. telecommunications infrastructure
e. roads (and ports) infrastructure
f. energy infrastructure
g. regulatory environment (tax, labour law)
h. location (land, building, sanitation).

Local government is the prime actor in establishing people infrastructure and controlling location (a and h). It plays an important, but not primary role in roads, energy and the regulatory environment (through property taxes). Its role in financial, skills and telecommunications infrastructure is limited. This sliding scale coincides with the relationship with the built environment: the more the function has to do with the built environment, the more intense local government's involvement should be. This indicator demonstrates that it is essential for municipalities to have authority over the housing function in order for them to discharge their responsibilities for the built environment.

\section{Need for a New Approach}

Application of the above six indicators suggests that in the South African context, consideration should be given to transferring further functions to local government. Many of the arguments used against changing the content of Schedules 4B and 5B of the Constitution (the 'original' powers of local government) relate to fears of fragmentation and deterioration of services as a result. However, these arguments often overlook the reality that in South Africa, the fact that a power or competence is an 'original' local government function does not minimise oversight powers of national and/or provincial government. A municipality's authority over its 'original' functions is anything but unfettered. National and provincial government oversees municipal performance of 'original' functions through the legislative framework within which municipalities must operate. ${ }^{11}$

Any review of local government powers and functions therefore requires a nuanced approach which focuses on specific functions and assesses whether there is a need for greater local government involvement. In the South African context this approach should be guided by the following two questions. First, does the absence of the function from Schedules $4 \mathrm{~B}$ or $5 \mathrm{~B}$ make the Schedules an inadequate reflection of developmental local government? If so, there is an argument to revisit the Schedules on this matter. Second, should (certain) municipalities be afforded policy-making authority over a function that is not currently allocated to local government? If so, the assignment of the function to local government may be considered.

\footnotetext{
11 s155(7) of the Constitution confers the power on national government to 'regulate' the exercise by municipalities of their executive authority. The term 'regulating' in the context of section 155(7) of the Constitution was interpreted by the Constitutional Court to mean 'a broad managing or controlling rather than direct authorisation function'. This relates to the framework within which local government must exercise these powers. In other words, the regulatory power enables national government (and also provincial government) to set essential national standards, minimum requirements, monitoring procedures etc.
} 
There are two key aspects here. First, the transfer of functions to local government must be consistent with the procedures in the Constitution and the Municipal Systems Act. Second, the 'one-size-fits-all' approach to municipal functions needs to give way to a nuanced and differentiated approach that takes into account spatial and economic realities, as well as capacity constraints currently facing municipalities.

The challenge of creating integrated sustainable cities, with the marginalised in our society sharing in the benefits of developmental local government, is immense. The metros, by and large the success stories of local government in South Africa, need to be the drivers of developmental processes within their jurisdiction with minimal provincial and national government interference. An asymmetrical approach must be taken to local government to allow for the development of capacity where lacking. Capacity must, however, be developed in a manner that would sustain local government delivery. In the budget speech delivered by the then Minister for Provincial and Local Government, Sydney Mufamadi, he emphasised that "priority attention must be paid to ensuring that improved local government performance becomes a self-sustaining dynamic" (Mufamadi 2008).

In view of the upcoming 2009 elections, the outcomes of the review of provincial and local government will not only impact the shape and form that local government will take in the future, but importantly, the political attitude manifested towards local government. The review process poses key questions which ask whether the current configuration of provincial and local government has improved the delivery of basic social services and deepened democracy in the new South Africa. It is hoped that the answers to these questions would fundamentally change the face of local government in a manner that will result in better service delivery and, ultimately, better lives for all South African citizens.

\section{References}

De Visser, J. 2008. 'Heeding the call for sustainable energy use - putting solar energy to work', Local Government Bulletin, vol. 10(4).

Department of Housing KwaZulu-Natal, 2005. 'Resolutions of the KwaZulu-Natal Housing Summit', 23-24 March 2005, Coastlands Conference Centre, Durban, viewed 14 May 2007, <http://www.kznhousing.gov.za/conference/kzn>.

Department of Provincial and Local Government, 2007. Guidelines on Allocation of Additional Powers and Functions to Municipalities, Department of Provincial and Local Government, Pretoria.

Governing Council of the United Nations Human Settlements Programme, 2007. Draft guidelines on Decentralization and the Strengthening of Local Authorities HSP/GC/21/2/L.3.

Mufamadi, F.S. 2008. Budget Speech, Minister for Provincial and Local Government, 3 June. Cape Town, South Africa.

Constitution of the Republic of South Africa, 1996. (Republic of South Africa).

National Housing Code 1997. (Republic of South Africa).

Local Government: Municipal Systems Act 32 of 2000 (Republic of South Africa). 
South African Cities Network, 2005. 'City statistics- South African Cities and GDP', viewed 13 October 2008, <http://www.sacities.co.za/left/stats.stm>.

South African Local Government Association, 2007. 'Working Group Four: 2007', Conference Paper.

Triegaardt, J.D. 2008, 'Reflections on Poverty and Inequality in South Africa: Policy Considerations in an Emerging Democracy', viewed 16 October 2008, $\langle$ http://www.cosatu.org.za/docs/2007/reflect.pdf>.

Tsenoli, L. 2007. Speech, 'Local Government and Metropolitan Regions' Roundtable hosted by the Community Law Centre, 8-9 February. Cape Town, South Africa.

World Bank, 2008. 'Country Brief - South Africa', viewed 14 October 2008. $\langle$ http://go.worldbank.org/GSBYF92330〉.

Zille, H. 2007, Speech 'Business Meets City', 24 April. Cape Town, South Africa. 